\title{
Association between cell wall-related processes and functionally non-annotated factors important for K2 susceptibility
}

\author{
Juliana Lukša ${ }^{1}$, \\ Iglè Vepštaite்', \\ Elena Serviené $\dot{1}^{1,2^{*}}$ \\ ${ }^{1}$ Laboratory of Genetics, \\ Institute of Botany, \\ Nature Research Centre, \\ Akademijos St. 2, \\ LT-08412 Vilnius, Lithuania \\ ${ }^{2}$ Department of Chemistry and Bioengineering, \\ Faculty of Fundamental Sciences, \\ Vilnius Gediminas Technical University, \\ Sauletekio Ave. 11, \\ LT-10223 Vilnius, Lithuania
}

\begin{abstract}
Seventy one genes, previously determined as important for K2 killer protein susceptibility and not annotated in the Saccharomyces Genome Database (SGD), were analyzed by applying computational analysis and investigation of toxin binding efficiency. Links between 44 unknown ORF products and proteins related to cell wall processes were observed. Out of them, 17 single gene knockout mutants express the altered K2 toxin binding phenotype. The comparison of both approaches allowed assignment of 6 previously non-annotated gene products (Slp1, Tda1, Nba1, Ecm3, Ykr046C, and Ybr287W) as functionally associated with cell wall structure maintenance and biogenesis processes, confirming possible involvement in $\mathrm{K} 2$ receptor formation.
\end{abstract}

Key words: Saccharomyces cerevisiae, K2 toxin susceptibility, gene annotation

\section{INTRODUCTION}

The widespread killer phenomenon in yeast is based on the secretion of the killer toxin, lethal to sensitive strains of the same species as well as to a wide spectrum of other yeast genera. The characterization of such toxins has consistently provided significant insights into the basic mechanisms of self-defense, virus-host cell interactions, and toxin entry into the target cell (Schmitt, Breinig, 2006).

The study of the functioning of Saccharomyces cerevisiae $\mathrm{K} 1, \mathrm{~K} 2$ and $\mathrm{K} 28$ killer toxins revealed them having rather distinct modes of the ac-

\footnotetext{
* Corresponding author. E-mail: elena.serviene@vgtu.lt
}

tion, either relaying on disruption of the ionic potential across the membranes or interruption of cell division by blocking DNA synthesis (Frank, Wolfe, 2009). Many cellular factors play important roles in modulation of the response to a particular toxin. By performing genomewide screens hundreds of such effectors, both unique and common for all toxins, were identified. The susceptibility to the K1 toxin is conferred by gene products related to specific areas of cellular activity, including synthesis of cell wall components, secretion pathway, lipid and sterol biosynthesis, and cell surface signal transduction (Pagé et al., 2003). Genes, whose deletion causes hypersensitivity to the K28 toxin, are related to stress-activated signaling and protein 
degradation, whereas resistant mutants are linked to endocytic, lipid organization and cell wall biogenesis pathways (Carroll et al., 2009). Genes involved in resistance to the K2 toxin are directly connected to the cell wall structure/biogenesis and the mitochondrial function; hypersensitive mutants are deficient of genes known to be involved in osmosensory and cell wall stress signaling, ion and $\mathrm{pH}$ homeostasis maintenance (Serviene et al., 2012). Among single-gene deletion mutants possessing altered susceptibility to a particular toxin, a large group was functionally not characterized in the Saccharomyces Genome Database (SGD) or even called as "dubious ORFs", indicating uncertainty for them to be true genes (Pagé et al., 2003; Pena-Castillo, Hughes, 2007; Carroll et al., 2009; Serviene et al., 2012). For the ORFs annotation computational predictions from genome sequences combined with experimental verification were usually applied. The use of current genomic, transcriptomic and proteomic approaches still provides not enough information for assignment of specific functions to all unknown genes (Li et al., 2008). Therefore, further efforts of scientists in different fields are necessary for understanding of the biological role of particular nonannotated ORFs.

In this study, we investigated possible functional and structural interactions between non-annotated gene products, important for K2 susceptibility, and proteins, involved in the cell wall structure and biogenesis. We built a possible protein-protein interaction network and tested the K2 toxin binding efficiency to a deficient in particular ORF yeast mutant. The comparison of computational analysis and experimental data allowed assigning previously uncharacterized ORFs to be functionally related to the cell wall processes and important for K2 toxin receptors formation.

\section{MATERIALS AND METHODS}

The S. cerevisiae strain M437 (wt, HM/HM [kil-K2]) was used to isolate the K2 toxin (Gulbiniene et al., 2004). The $S$. cerevisiae paren- tal strain (MATa; his $3 \Delta 1$; leu $2 \Delta 0$; met $15 \Delta 0$; ura $\Delta \Delta 0$ ) and single ORF-deletion mutants (Table 1) created on the background of the BY4741 strain were purchased from Thermo Scientific Molecular Biology (Lafayette, CO, USA) and used for K2 sensitivity, toxin binding analysis and interaction network construction.

Yeast strains were grown in the standard YEPD medium ( $1 \%$ yeast extract, $2 \%$ peptone, $2 \%$ glucose, $2 \%$ agar). For $\mathrm{K} 2$ toxin sensitivity, the MBA medium $(0.5 \%$ yeast extract, $0.5 \%$ peptone, $2 \%$ dextrose), adjusted to pH 4 with the $75 \mathrm{mM}$ phosphate-citrate buffer, supplemented with $0.002 \%$ methylene blue dye, was used. The synthetic SC medium (2\% glucose, $6 \mathrm{mM} \mathrm{K}_{2} \mathrm{HPO}_{4}, 8 \mathrm{mM} \mathrm{MgSO}_{4}, 8 \mathrm{mM}$ $\left.\left(\mathrm{NH}_{4}\right)_{2} \mathrm{SO}_{4}\right)$, adjusted to $\mathrm{pH} 4$ and containing $5 \%$ glycerol, was used for the isolation of the $\mathrm{K} 2$ toxin.

For K2 toxin production, the S. cerevisiae strain M437 was grown in the synthetic SC medium for 4 days at $18{ }^{\circ} \mathrm{C}$. Yeast cells were sedimented by centrifugation at $3,000 \times \mathrm{g}$ for $10 \mathrm{~min}$, the supernatant was filtered through a $0.22 \mu \mathrm{m}$ sterile polyvinylidene fluoride membrane and concentrated by ultrafiltration through an Amicon PM-10 membrane. Such toxin isolate was used for analysis of not annotated in the S. cerevisiae Genome Database (SGD) single-gene deletion mutants (Gulbiniene et al., 2004; Serviene et al., 2012).

For testing of susceptibility to the K2 killer toxin, the well assay was applied. The yeast mutant was seeded into the MBA medium $\left(2 \times 10^{6}\right.$ cells/plate $)$, and $100 \mu \mathrm{L}$ of the concentrated supernatant of the $\mathrm{K} 2$ toxin was poured into $10 \mathrm{~mm}$ wide wells cut in the agar layer. Plates were incubated for 2 days at $25^{\circ} \mathrm{C}$, nongrowth zones around the wells were measured and compared to the zones formed on the parental control strain BY4741 layer.

To investigate possible functional and structural interactions between particular proteins, the STRING web resource was used. The created network uses the "confidence view" option of the program, where stronger associations are represented by thicker lines. 
Table 1. Non-annotated in SGD genes, whose deletion causes altered K2 resistance. The K2 toxin susceptibility scoring categories based on the lysis zone: $\mathrm{R}$ is resistant: $\mathrm{R}++(0.5-1 \mathrm{~mm}$ radius $), \mathrm{R}+(1-1.5 \mathrm{~mm}$ radius), $\mathrm{R}+\mathrm{l}-(1.5-2 \mathrm{~mm}$ radius); $\mathrm{S}$ is sensitive: $\mathrm{S}+/-(3-3.5 \mathrm{~mm}$ radius $), \mathrm{S}+(3.5-4 \mathrm{~mm}$ radius $), \mathrm{S}++$ (4-5 mm radius)

\begin{tabular}{|c|c|c|c|c|c|}
\hline $\begin{array}{l}\text { Standard } \\
\text { name }\end{array}$ & $\begin{array}{c}\text { Systematic } \\
\text { name }\end{array}$ & $\begin{array}{c}\text { K2 } \\
\text { susceptibility }\end{array}$ & $\begin{array}{c}\text { Standard } \\
\text { name }\end{array}$ & $\begin{array}{c}\text { Systematic } \\
\text { name }\end{array}$ & $\begin{array}{c}\text { K2 } \\
\text { susceptibility }\end{array}$ \\
\hline AIM26 & YKL037W & $\mathrm{R}++$ & TOS7 & YOL019W & $\mathrm{R}+/-$ \\
\hline TOS1 & YBR162C & $\mathrm{R}++$ & PRG1 & DR065W & $\mathrm{R}+/-$ \\
\hline \multirow[t]{2}{*}{ IRC6 } & YFR043C & $\mathrm{R}++$ & POG1 & YIL122W & $\mathrm{R}+/-$ \\
\hline & YAL056C-A & $\mathrm{R}++$ & $P D P 3$ & YLR455W & $\mathrm{R}+/-$ \\
\hline \multirow[t]{3}{*}{$L D S$} & YOL047C & $\mathrm{R}+$ & & YNL217W & $\mathrm{R}+/-$ \\
\hline & YLR001C & $\mathrm{R}+$ & PAL1 & YDR348C & $\mathrm{R}+/-$ \\
\hline & YOL131W & $\mathrm{R}+$ & & YCR001W & $\mathrm{R}+/-$ \\
\hline \multirow[t]{2}{*}{ NCE101 } & YJL206C-A & $\mathrm{R}+$ & & YGR214W & $\mathrm{R}+/-$ \\
\hline & YOL036W & $\mathrm{R}+$ & & YGR290W & $\mathrm{R}+/-$ \\
\hline SLP1 & YOR154W & $\mathrm{R}+$ & & YLR111W & $\mathrm{R}+/-$ \\
\hline \multirow[t]{4}{*}{ ATG40 } & YOR152C & $\mathrm{R}+$ & & YNL179C & $\mathrm{R}+/-$ \\
\hline & YNL011C & $\mathrm{R}+$ & & YDL032W & $\mathrm{R}+/-$ \\
\hline & YBL044W & $\mathrm{R}+$ & NEL1 & YHR035W & $\mathrm{R}+/-$ \\
\hline & YDL073W & $\mathrm{R}+$ & YH19 & YHR029C & $\mathrm{S}+/-$ \\
\hline NBA1 & YOL070C & $\mathrm{R}+$ & PET10 & YKR046C & $\mathrm{S}+1-$ \\
\hline SPO23 & YBR250W & $\mathrm{R}+$ & & YPR013C & $\mathrm{S}+1-$ \\
\hline \multirow[t]{8}{*}{ RRG8 } & YPR116W & $\mathrm{R}+$ & GRE1 & YPL223C & $\mathrm{S}+1-$ \\
\hline & YDL041W & $\mathrm{R}+$ & & YCR087W & $\mathrm{S}+1-$ \\
\hline & YGR069W & $\mathrm{R}+$ & & YDR525W & $\mathrm{S}+/-$ \\
\hline & YKL131W & $\mathrm{R}+$ & & YGL024W & $\mathrm{S}+1-$ \\
\hline & YDL096C & $\mathrm{R}+$ & & YKL177W & $\mathrm{S}+/-$ \\
\hline & YMR193C-A & $\mathrm{R}+$ & & YLR402W & $\mathrm{S}+/-$ \\
\hline & YOL037C & $\mathrm{R}+$ & & YOR309C & $\mathrm{S}+1-$ \\
\hline & YDL009C & $\mathrm{R}+$ & & YBR287W & $\mathrm{S}+$ \\
\hline \multirow[t]{2}{*}{ JIP3 } & YLR331C & $\mathrm{R}+$ & & YNL234W & $\mathrm{S}+$ \\
\hline & YIR043C & $\mathrm{R}+$ & HGH1 & YGR187C & S+ \\
\hline LMO1 & YLL007C & $\mathrm{R}+$ & & YGR015C & $\mathrm{S}+$ \\
\hline \multirow[t]{6}{*}{ OSW5 } & YMR148W & $\mathrm{R}+1-$ & & YBL094C & $\mathrm{S}+$ \\
\hline & YMR178W & $\mathrm{R}+1-$ & & YDR455C & S+ \\
\hline & YMR206W & $\mathrm{R}+/-$ & & YGR164W & S+ \\
\hline & YNR040W & $\mathrm{R}+1-$ & & YNL120C & $\mathrm{S}+$ \\
\hline & YNR063W & $\mathrm{R}+1-$ & & YGR160W & S+ \\
\hline & YPR022C & $\mathrm{R}+1-$ & FYV4 & YHR059W & $\mathrm{S}+$ \\
\hline ECM3 & YOR092W & $\mathrm{R}+/-$ & LGE1 & YPL055C & $\mathrm{S}++$ \\
\hline TDA1 & YMR291W & $\mathrm{R}+1-$ & $B R P 1$ & YGL007W & $\mathrm{S}++$ \\
\hline RRT8 & YOL048C & $\mathrm{R}+1-$ & & & \\
\hline
\end{tabular}

The experiments-based active prediction method was used, and the confidence of score 0.15 was utilized (Szklarczyk et al., 2011).

To assess binding of the $\mathrm{K} 2$ toxin to the appropriate yeast, $1 \times 10^{6}$ cells of a mutant or a parental strain were incubated in $1 \mathrm{ml}$ of a K2-containing supernatant (about $100 \mathrm{pg}$ of toxin) for $15 \mathrm{~min}$ at $4^{\circ} \mathrm{C}$. The supernatant was then collected by centrifugation $(10,000 \times \mathrm{g}$, $1 \mathrm{~min}$ ), and the remaining $\mathrm{K} 2$ killer activity was tested on a sensitive $a^{\prime} 1$ strain overlay using the well test. The binding level was 
expressed as the percentage of toxin activity obtained for each mutant compared to the one of the non-incubated with the cells $\mathrm{K} 2$ toxin (Lukša et al., 2015).

\section{RESULTS AND DISCUSSION}

S. cerevisiae single gene deletion strains (4774) were previously tested for susceptibility to the K2 toxin (Serviene et al., 2012). It was identified that defects in the 332 ORFs condition increased resistance or sensitivity to this killer protein. We observed that 44 strains out of 322 belong to a group of unknown molecular functions in the Saccharomyces cerevisiae Genome Database (SGD) and 27 strains carry the suffix "dubious ORFs". By performing the K2 susceptibility test we established that 49 out of 205 deletion mutants demonstrating an increased toxin resistance phenotype were uncharacterized gene products, while from 127 toxin-sensitive deletion strains 22 were non-annotated. Deletion of YKL037W, YBR162C, YFR043C and YAL056C-A RFs determined the highest resistance to the $\mathrm{K} 2$ toxin $(\mathrm{R}++)$ compared to other deletion strains analyzed, resulting in the formation of non-lysis zones (Table 1). Excision of 23 functionally unknown ORFs condition moderate resistance phenotype $(\mathrm{R}+)$ and 22 gene deletions resulted in a minor increase of resistance $(\mathrm{R}+/-)$. The analysis of hypersensitive mutants showed that deletion of YHR059W, YPL055C and YGL007W ORFs resulted in the strongest hypersensitivity phenotype $(\mathrm{S}++)$ from the non-annotated mutants tested. The size of non-growth zones formed by the K2 toxin on such a mutant layer was about 2 fold bigger compared to ones observed on parental strain-seeded MBA plates. Deletion of 9 ORFs resulted in a moderate alteration in sensitivity to the $\mathrm{K} 2$ toxin $(\mathrm{S}+)$, and elimination of the rest 10 ORFs indicated a low change of sensitivity (S+/-) (Table 1$)$.

It is established that the $\mathrm{K} 2$ toxin is active at the cell wall, where it binds to the receptors and disrupts the functional and/or structural integrity of the plasma membrane (Dig- nard et al., 1991; Luksa et al., 2015). It was also found that defects in the cell wall protein mannosylation and $\beta$-1.6-glucan synthesis caused the resistance to the $\mathrm{K} 2$ toxin, since these components are directly related to formation of the toxin binding receptors (Luksa et al., 2015), and changes in the cell wall structure can influence yeast cell properties towards the K2 toxin (Serviene et al., 2012).

We were interested in finding out whether the non-annotated gene products interact physically and/or functionally with proteins involved in the cell wall structure and biogenesis. For this, we built interaction networks using a STRING search tool and found that 44 out of 71 functionally non-annotated gene products were interconnected with the same group of unknown proteins or interacted with CW-related proteins (Fig. 1). Since not much datasets are available in the literature concerning analysis of non-annotated or weaklydescribed gene products, the majority of associations are not strong and represented in the network by thin lines. On the other hand, it is possible that weak interconnections are conditioned by missing links between certain genes. Still, some gene products such as encoded by YOR309C, YGR187C (HGH1), YOR154W (SLP1) and YMR291W (TDA1) have stronger associations, represented by thicker lines. Moreover, they link directly by weak bonds to the $\mathrm{CW}$-associated proteins Smi1 and Rot2, important for CW synthesis.

Two gene products, encoded by YDR065W $(R R G 1)$ and YPR116W (RRG8), are interconnected by thick lines and have direct connectivity to the GTPase activating protein Lrg1, important for maintenance of cell wall integrity. A couple of proteins encoded by YBR162C (TOS1) and YDL041W are interconnected by a medium confidence score through Tos1 associated with many cell wall proteins, such as Srl1, Scw4, Ccw12, Uth1 and Fks1. Interestingly, in our network a dubious open reading frame YLR111W, based on the SGD annotation, unlikely to encode a functional protein, has a strong association 


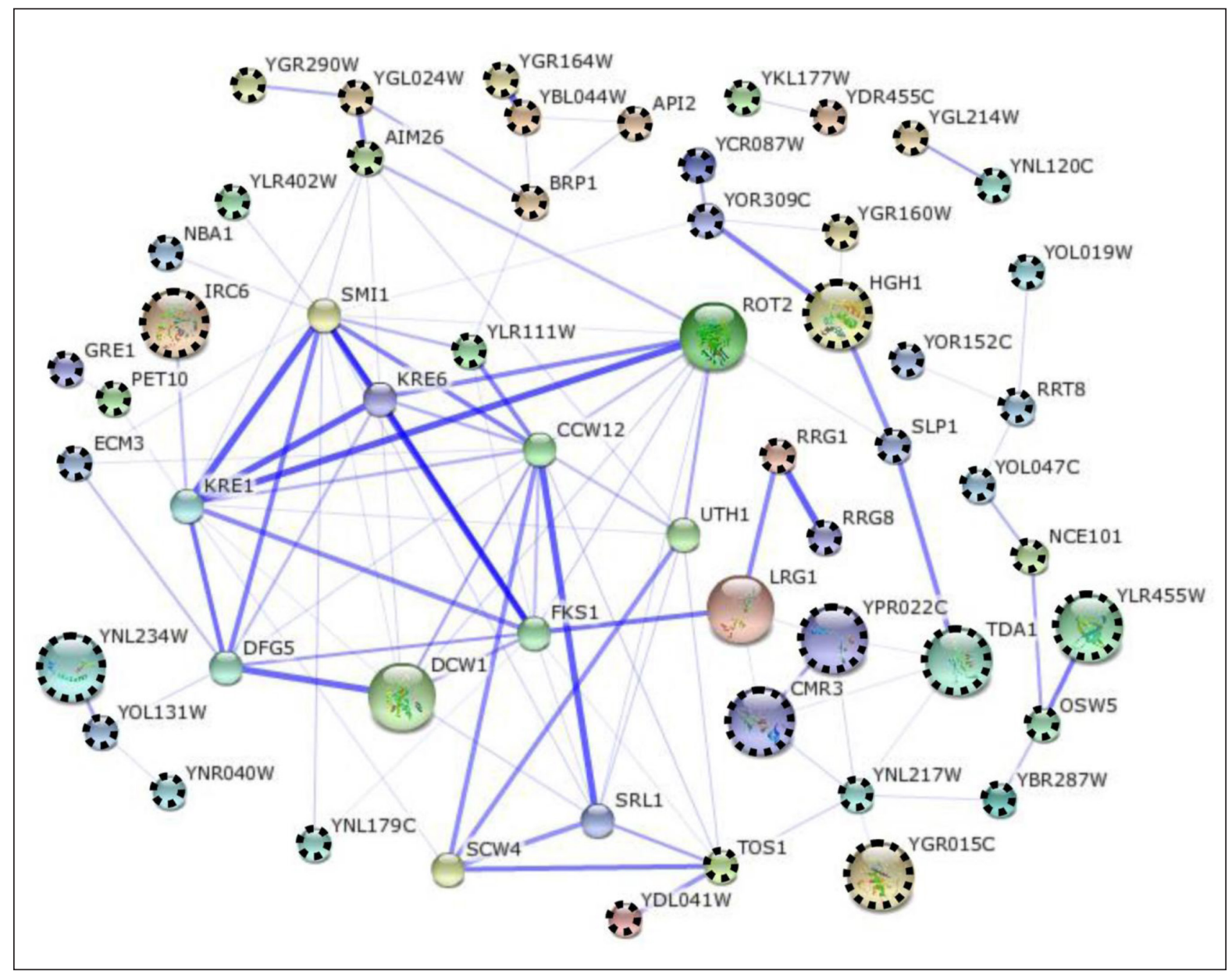

Fig. 1. STRING mapping profiles of the protein interaction network representing functionally non-annotated (marked with black dots) and cell wall associated (unmarked) gene products. Stronger associations are represented by thicker lines

with the cell wall mannoprotein Ccw12 and CW integrity regulator Smil. Our networkbased data demonstrate that at least some of the uncharacterized gene products, involved in $\mathrm{K} 2$ toxin resistance formation, are directly involved in the $\mathrm{CW}$-linked processes.

In order to define the function of uncharacterized genes, the ability of yeast mutants to bind the K2 toxin was analyzed. The toxin binding assay is based on measuring of the remaining killing activity of K2 toxin preparations, following incubation either with reference BY4741 cells or with the mutant of interest. We identified 17 single-gene deletion mutants, which showed altered binding efficiency (Fig. 2).
Eleven uncharacterized gene mutants after incubation with the $\mathrm{K} 2$ toxin did not form lysis zones at all (YBL094C, YBR287W, YLR001C, YKR046C and YHR059W) or formed zones are small (YGR187C, YDR348C, YNL120C, YNR063W, YGR160W and YPR022C). This means that a large amount of the $\mathrm{K} 2$ toxin binds to the cell wall receptors and residual $\mathrm{K} 2$ toxin activity is substantially decreased. The K2 toxin binding efficiency is decreased in yeast strains with single deletion of YMR291W, YOR154W, YMR206W, YOL070C, YOR092W and YKL037W. The residual toxin activity after incubation with the mentioned above mutants is higher, compared to that incubated with the parental strain BY4741. 


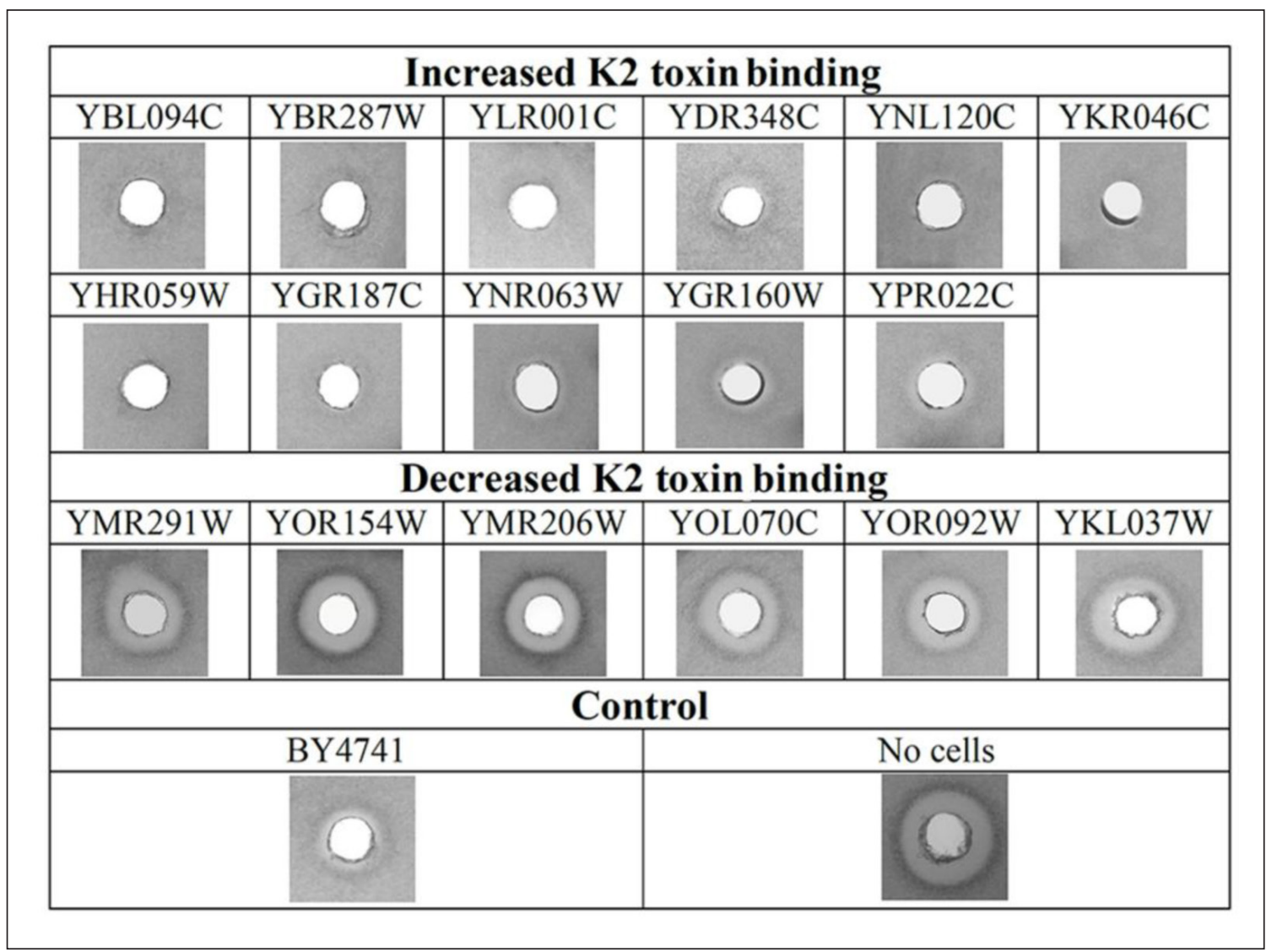

Fig. 2. Residual K2 toxin activity remaining after binding to wild type or mutant cells. Increased K2 binding is distinguished by formed lysis zones (less than $0.75 \mathrm{~mm}$ ) and diminished binding lysis zones (more than $3 \mathrm{~mm}$ )

\section{CONCLUSIONS}

The comparison of non-annotated gene products interconnected in the interaction network and demonstrating altered $\mathrm{K} 2$ binding efficiency revealed that 6 yeast strains were common in both tests. Deletions of four genes, as SLP1, TDA1, NBA1 and ECM3, conditioned decreased $\mathrm{K} 2$ toxin binding and thus increased resistance to the killer protein. Elimination of YKR046C and YBR287W ORFs stipulated increased $\mathrm{K} 2$ toxin binding and thus increased hypersensitivity to the $\mathrm{K} 2$ killer protein. Our data reveal that all these gene products, important for $\mathrm{K} 2$ resistance formation, are associated with the cell wall structure or biogenesis and are most likely involved in the formation of the CW-localized $\mathrm{K} 2$ receptors.

\section{ACKNOWLEDGEMENTS}

This work was supported by a grant of the Research Council of Lithuania (LMT) No. MIP-042/2013.

Received 3 May 2015 Accepted 22 July 2015

References

1. Berger KH, Yaffe MP. Mitochondrial DNA inheritance in Saccharomyces cerevisiae. Trends Microbiol. 2000; 8: 508-13.

2. Carroll SY, Stirling PC, Stimpson HEM, Gießelmann E, Schmitt MJ, Drubin DG. A yeast killer toxin screen provides insights 
into $\mathrm{A} / \mathrm{B}$ toxin entry, trafficking and killing mechanisms. Dev Cell. 2009; 17: 552-60.

3. Dignard D, Whiteway M, Germain D, Tessier D, Thomas DY. Expression in yeast of a cDNA copy of the K2 killer toxin gene. Mol Gen Genet. 1991; 227: 127-36.

4. Frank AC, Wolfe KH. 2009. Evolutionary capture of viral and plasmid DNA by yeast nuclear chromosomes. Eukaryotic Cell. 8(10): 1521-31.

5. Gulbiniene G, Kondratiene L, Jokantaite T, Serviene E, Melvydas V, Petkuniene G. Occurrence of killer yeast strains in fruit and berry wine yeast populations. Food Technol Biotechnol. 2004; 42: 159-63.

6. Li QR, Carvunis AR, Yu H, Han JD, Zhong Q, Simonis N, et al. Revisiting the Saccharomyces cerevisiae predicted ORFeome. Genome Res. 2008; 18: 1294-303.

7. Lukša J, Podoliankaitè M, Vepštaitė I, Strazdaité-Žielienè Ž, Urbonavičius J, Servienè E. Yeast $\beta$-1,6-glucan is a primary target for the Saccharomyces cerevisiae K2 toxin. Eukaryot Cell. 2015; 14: 406-14.

8. Magliani W, Conti S, Gerloni M, Bertolotti D, Polonelli L. Yeast killer systems. Clin Microbiol Rev. 1997; 10: 369-400.

9. Pagé N, Gérard-Vincent M, Ménard P, Beaulieu M, Azuma M, Dijkgraaf GJP, et al. A Saccharomyces cerevisiae genome-wide mutant screen for altered sensitivity to K1 killer toxin. Genetics. 2003; 163: 875-94.

10. Pastor MM, Proft M, Pascual-Ahuir A. Mitochondrial function is an inducible determinant of osmotic stress adaptation in yeast. J Biol Chem. 2009; 284: 30307-17.

11. Pena-Castillo L, Hughes TR. Why are there still over 1000 uncharacterized yeast genes? Genetics. 2007; 176: 7-14.

12. Schmitt MJ, Breinig F. Yeast viral killer toxins: lethality and self-protection. Nat Rev Microbiol. 2006; 4: 212-21.
13. Servienè E, Lukša J, Orentaitè I, Lafontaine DLJ, Urbonavičius J. Screening the budding yeast genome reveals unique factors affecting K2 toxin susceptibility. Plos One. 2012; 7: e50779.

14. Sickmann A, Reinders J, Wagner Y, Joppich C, Zahedi R, Meyer HE, et al. The proteome of Saccharomyces cerevisiae mitochondria. Proc Natl Acad Sci USA. 2003; 100: 13207-12.

15. Szklarczyk D, Franceschini A, Kuhn M, Simonovic M, Roth A, Minguez $\mathrm{P}$, et al. The STRING database in 2011: functional interaction networks of proteins, globally integrated and scored. Nucleic Acids Res. 2011; 39: D561-68.

Juliana Lukša, Iglè Vepštaitė, Elena Servienè

\section{NEANOTUOTŲ GENETINIŲ VEIKSNIŲ SĄSAJOS SU LĄSTELÉS SIENELÉS PROCESAIS}

\section{Santrauka}

Atlikti tyrimai suteikia naujų žinių apie funkciniu požiūriu nežinomų Saccharomyces cerevisiae ASR charakterizavimą. 71 neanotuotas Saccharomyces Genomo duomenų bazèje ir susijęs su jautrumo K2 toksinui formavimu genas buvo tirtas taikant kompiuterinę analizę ir nustatant toksino surišimo efektyvumą. Apibrèžti ryšiai tarp 44 necharakterizuotų ir su ląstelès sienelès procesais susijusių baltymų. Nustatyti K2 toksino surišimo pokyčiai 17 neanotuotų mutantų. Palyginamoji kompiuterinių ir eksperimentinių tyrimų analizė leido funkciškai susieti 6 genų produktus (Slp1, Tda1, Nba1, Ecm3, Ykr046C ir Ybr287W) su ląstelès sienelès struktūros palaikymo ir biogenezès procesais bei apibrèžti tikètiną dalyvavimą formuojant K2 receptorių.

Raktažodžiai: Saccharomyces cerevisiae, jautrumas K2 toksinui, genų charakterizavimas 